Андрей Можайский

ORCID: 0000-0003-1112-2858

Институт классического Востока и античности, Национальный исследовательский университет

«Высшая школа экономики»

Институт стратегии развития образования Российской академии образования

Москва, Россия

\title{
Этеокл как мужской персонаж трагедии Әсхила Семеро против Фив
}

https://doi.org/10.34739/clit.2021.15.04

\author{
Eteocles as a Male Character \\ of Aeschylus's Tragedy Seven against Thebes
}

This article analyzes the text of Aeschylus's tragedy Seven against Thebes in the context of one of the main characters - Eteocles - as a male character. In the text of Aeschylus, Eteocles looks like a tough ruler who is endowed with certain masculine qualities. Moreover, through his words, the male character is sometimes expressed. This helps him save his hometown, but at the same time leads him to death. According to Eteocles, the men of Thebes in the face of the enemy must protect their Mother Earth with shields in their hands. In addition to identifying a warrior with a shield, Aeschylus, through the words of Eteocles, indicates that the place of the male protector is on the battlements and in the gates with towers. According to Aeschylus, Eteocles is the bravest master (king) of the Cadmeans. The use of the word öva $\xi$ in relation to Eteocles reflects the archaic nature of the story of Seven against Thebes. Eteocles as a male character is not just the bravest king of the Cadmeans, but he also pretends to be a wise ruler. According to Aeschylus, Eteocles is an almost exclusively positive male character, despite the fact that he indicates that evil has been done to Polyneices.

Keywords: Eteocles, male character, Aeschylus, Seven against Thebes, warrior, shield, anax

В данной статье проанализирован текст древнегреческого драматурга Эсхила Семеро против Фив в контексте одного из главных героев - Этеокла - как мужского персонажа. Именно этот персонаж представлен Әсхилом как мужественный правитель, способный защитить свое отечество. Согласно мнению исследователей, временем создания данного произведения считается период от 475 по 470 гт. до 
н.э. ${ }^{1}$. Сюжет произведения развивается вокруг конфликта между сыновьями Эдипа - царем Фив Этеоклом и его братом Полиником, который с войском из Пелопоннеса приходит к Фивам и пытается оспорить власть брата. Вместе с Полиником в походе против Фив участвуют еще шестеро героев, которые руководят отрядами. Таким образом, семь предводителей атакуют семь ворот Кадмеи - акрополя Фив ${ }^{2}$. Этим семерым нападающим противостоят семь защитников Фив,

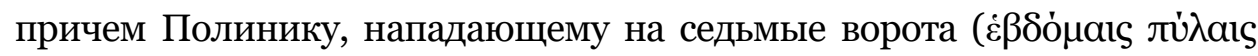
(Sept. 631, 80о))3, противостоит царь Фив - Этеокл. Фиванцы смогли отбить атаку, причем предводители нападающих гибнут под Фивами, однако и братья - Этеокл с Полиником - гибнут, убив друг друга. Трагедия заканчивается тем, что глашатай сообщает решение фиванского совета4 относительно погребения Этеокла и Полиника. Этеокла постановили похоронить, а тело Полиника выбросить без

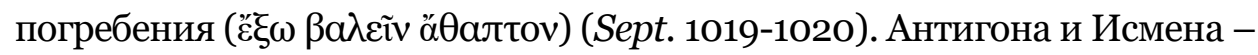
сестры погибших братьев - оплакивают их, после чего Антигона решает похоронить Полиника, вопреки постановлению совета. Часть хора поддерживает решение Антигоны, а часть поддерживает постановление совета и прославляет Этеокла.

В тексте Эсхила Этеокл выглядит жестким и в некоторой степени рациональным правителем, который наделен определенными

${ }^{1}$ C. Zimmermann, Der Antigone-Mythos in der antiken Literatur und Kunst, Tübingen 1993, p. 81; S. Mills, Theseus, Tragedy and the Athenian Empire, Oxford 1997, p. 233; A.S. Anderson, The Seven Against Thebes at Eleusis, „Illinois Classical Studies” 2015, Vol. 40, No. 2, pp. 307-308. 2 О воротах Кадмеи и их расположении с пространной библиографией вопроса см.: А.Ю. Можайский, Реки и ворота Фив в трагедиях Эсхила, Софокла и Еврипида как часть образовательного пространства города, „Нуроthekai” 2018, No. 2, С. 79-96. Отметим, что в приведенной публикации мы приводим аргументацию в пользу того, что Фивы микенского времени действительно могли иметь семь ворот.

3 Остается неясным назывались ли эти ворота Седьмыми или Эсхил называет данные ворота по номеру перечисления, см.: S. Symeonoglou, The Topography of Thebes from the Bronze Age to Modern Times, Princeton 1985, p. 197; A.Yu. Mozhajsky, The myth of the War of the Seven and Pausanias' educational topography, „Нуроthekai” 2020, No. 4, p. 190. Однако, учитывая, что фиванские информаторы Павсания показывали ему место дуэли напротив Неистейских ворот (Paus. 25,1-2), а Еврипид (Phoen. 1570) помещает место дуэли у ворот Электры, то Седьмые ворота Эсхила могут быть седьмыми по номеру и в результате ошибки (ведь Эсхил ставит нападающего с именем Этеокл (Sept. 458-460) к Неистейским воротам) соответствовать Неистейским воротам Павсания.

4 Дословно глашатай у Эсхила говорит: «Мнение и постановления возвестить я должен

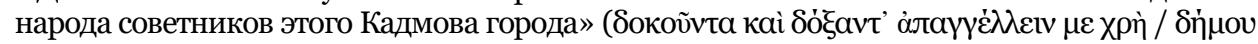

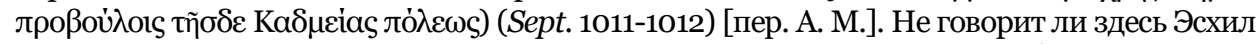
о современном ему устройстве управления Фивами? Этот вопрос требует отдельного разбора, однако, обратим внимание на то, что данный фрагмент может оказаться весьма важен для реконструкции политического устройства Фив в первой половины V в. до н.э. 
мужскими качествами. Более того, через речь Этеокла можно проследить, что Эсхил понимает под мужским делом во время угрозы родному городу. При этом, мужественность Этеокла, с одной стороны, помогает ему спасти родной город, а с другой - приводит царя к гибели.

Быть мужчиной в трагедии Эсхила Семеро против Фив. Уже в начале пролога Эсхил вкладывает в уста Этеокла слова, которые характеризуют представление автора (или представление автора о том, что должен в этом отношении думать Этеокл) о предназначении мужского населения Фив (Sept. 10-20). Приведем этот фрагмент в переводе С. Апта:

Итак, теперь вы все, и кто по возрасту

Еще не крепок телом, и кто во цвете лет

Играет силой мужественной зрелости 5 , Должны как подобает показать себя, Должны спасти свой город, отстоять должны

Немеркнущую славу алтарей родных,

Детей своих и родину-кормилицуб,

Земля которой ласково взрастила вас,

Заботы воспитанья на себя приняв,

Чтоб в нужный час по долгу по сыновнему

Вы со щитами7 вышли на священный бой.

Как видно, из предложенного фрагмента, мужчины Фив перед лицом врага должны защитить свою Землю-мать со щитами в руках. Надо сказать, что отождествление мужчины именно с щитоносцем

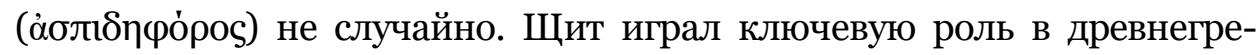
ческой культуре, которая несомненно была именно мужской. Это хорошо видно по произведениям Гомера, Гесиода, Эсхила и других авторов $^{8}$ В одной из недавних статей мы исследовали феномен щита

\footnotetext{
5 Если переводить дословно, то здесь нет слова «мужественной». Оригинальный текст

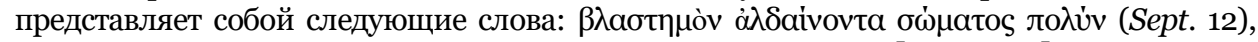
которые можно перевести как «рост укрепляющий силу тела» [пер. А. М.].

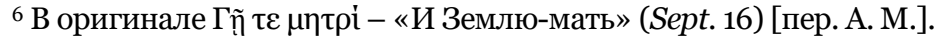

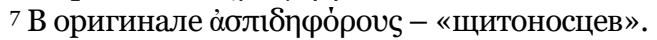

8 Cm.: N. Bershadsky, The Unbreakable Shield: Thematics of Sakos and Aspis, „Classical Philology” 2010, Vol. 105, No. 1, pp. 1-24. Следует отметить также значение изображений на щитах в эпической поэзии и других литературных произведениях. Особенно значимы изображения на щитах Ахиллеса, Геракла и ряда других героев, включая героев традиции о Семеро против Фив, см.: P.R. Hardie, Imago Mundi: Cosmological and Ideological Aspects of the Shield of Achilles, „The Journal of Hellenic Studies” 1985, Vol. 105, pp. 11-31; T.S. Heckenlively, The Shield of Herakles: a Study in Archaic Greek Poetics and the
} 
для фиванской культуры и пришли к выводу, что одними из наиболее важных традиций о щите в Фивах являются традиции о щите Амфиарая (один из семи нападающих на Фивы) и о дарах лидийского царя Креза в Фивы, который не случайно посвятил именно в святилище Амфиарая

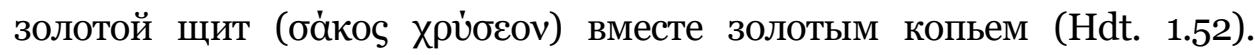
Рассматривая наличие в литературных источниках, начиная с гомеровских поэм, употребление относительно героических щитов

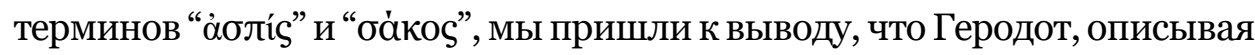
дары Креза в Фивах, использует слово “ба́коৎ”, тем самым подчеркивая необычность золотого щита, его героическую древность и божественную природу - надежность щита Амфиарая9.

Помимо отождествления воина со щитом, Эсхил устами Этеокла указывает, что место мужчины - быть защитником на зубчатых стенах

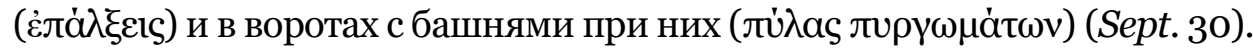
Это коррелирует с эпитетом Фив в̇лта́лטגоऽ - «семивратные», который известен по Одиссее. Берман полагает, что миф об основании Фив Амфионом и Зетом, который содержится в Одиссее (11.260-5), имеет корни в микенском периоде и сфокусирован на фортификации ${ }^{10}$. Мы также полагаем, что Фивы могли иметь семь ворот уже в микенское время, и в этом отношении текст Эсхила основан на знании реальной топографии и монументов ${ }^{11}$.

Отметим, что Вестник называет Этеокла храбрейшим

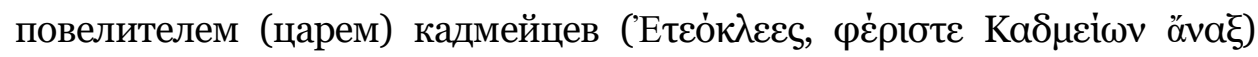
(Sept. 39). Эпитет фє́рıбтоৎ - храбрейший характерен для гомеровских поэм и является одним из главных мужских эпитетов. Именно так определяется величественный мужской эпитет в Илиаде (Il. 9.110):

Iconography of Violence, PhD Dissertation, University of California, Santa Barbara 2004. Для нашей темы особенно интересно исследование В.К. Пичугиной, посвященное педагогическим аспектам изображений на щитах в Семеро против Фив. По мнению автора, Этеокл показывает себя как царь-наставник для народа, что наиболее полно отражено в сцене с описанием щитов, где Этеокл разгадывает военные загадки, которые требуют от него правильно расшифровать изображения на щитах противников, см.: V.K. Pichugina, The shield as pedagogical tool in Aeschylus' Seven Against Thebes, „Hypothekai” 2020, No. 4, pp. 121-170.

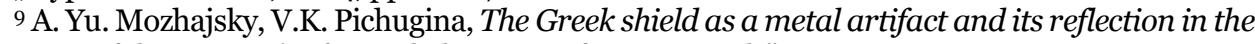
story of the Croesus' gifts in Thebes, „Non-ferrous Metals” 2020, No. 2, pp. 79-83.

${ }_{10}$ D.W. Berman, Cities-Before-Cities: 'Prefoundational' Myth and the Construction of Greek Civic Space, in Myth on the Map: The Storied Landscapes of Ancient Greece, ed. by G. Hawes, Oxford 2017, p. 37.

${ }^{11}$ А.Ю. Можайский, Реки и ворота Фив в трагедиях Эсхила, Софокла и Еврипида как часть образовательного пространства города, „Нуроthekai” 2018, No. 2, с. 79-96. 


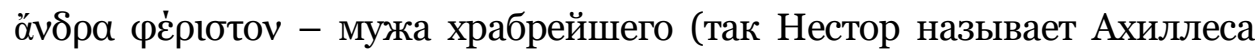
в речи к Агамемнону). Не случайно выбрано здесь и обращение о̆va повелитель (царь). Дело в том, что у Гомера этим обращением именуется Аполлон (Il. 1.390). Кроме того, именно этим словом

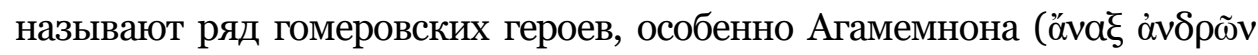
Аүa $\dot{\varepsilon}_{\mu \nu \omega v}$ - царь мужей Агамемнон (Il. 1.442)). Как пишет Чедвик, в классическом греческом языке существует два слова обозначающих «царь» - basileus и anax - но второе слово использовалось только в поэтическом языке, поэтому оно было известно как архаическое. Микенский язык имеет слово wanax, тоже слово, что и апax, как обычное слово для «царь», а микенский эквивалент для basileus использовался в более широком смысле, больше как английское „chief”" . Для нас важно, что использование слова öv $\alpha \xi$ отражает архаичность истории о Семерьх против Фив и отсылает нас в Поздний бронзовый век.

Кроме того, у Эсхила, Вестник сразу подчеркивает, что воин и есть

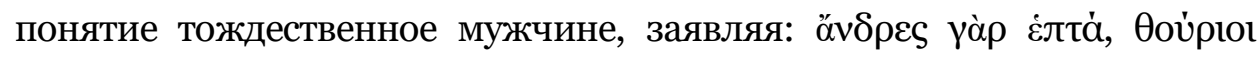

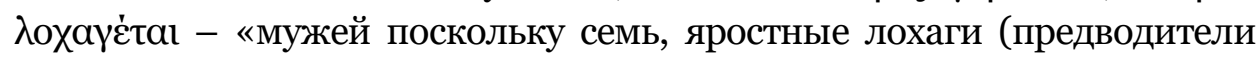
военных отрядов)» (Sept. 42) [пер. А. M.].

Против таких воинов, Вестник просит Этеокла поставить в воротах «лучших мужей» (á ческом языке слово ӧрібтоৎ определяется не только как лучший, храбрейший, но и как знатный ${ }^{13}$. Главное значение - лучший по рождению и положению. Именно происхождение главных защитников Фив будет подчеркивать Этеокл, перечисляя их, например, Меланипп (Sept. 412-413) или Мегарей (Sept. 474).

12 J. Chadwick, Linear B and related scripts, London 1987, p. 28. Интересно, что на современном этапе большинство исследователей полагают, что wanax, микенский правитель, получал большую часть своей власти от своего положения в религиозной сфере и что он председательствовал во время жертвенных празднеств, см.: S. Lupack, Mycenaean Religion, in The Oxford Handbook of the Bronze Age Aegean, ed. E.H. Cline, Oxford New York 2012, pp. 264-265 (с библиографией вопроса). Стефан Йорданов, проследил эволюцию этого термина применительно ко Фригии и царю Мидасу VIII в. до н.э., что находит свои параллели во Фракии и также, похоже, имеет божественную природу, см.: S. Yordanov, The "Decline" of Bronze Age Wanax: The Phrygian vanak-, the Priest-King, the 'Wanax to Basileus Model' and the Power Relations in Phrygian Society, „The Journal Epohi [Epochs]” 2020, Vol. XXVIII, Iss. 2, pp. 249-266. Таким образом, возможно, что в микенском обществе термин wanax подразумевал божественного сакрального царя, в то время как lavagetas - военного лидера.

13 H.G. Liddel, R. Scott, A Greek-English Lexicon, 9th ed., 1940, with a Revised Supplement (edited by P.G.W. Glare, with the assistance of A.A. Thompson), New York 1996, p. 241. 
Этеокл как мужской персонаж не просто храбрейший царь кадмейцев, но он еще и претендует на роль мудрого правителя, поскольку Вестник просит быть Этеокла «умным кормчим», которому нужно укрыть получше судно города, «прежде чем взыграет вихрь войны» (Sept. 62-64, пер. С. Апта) ${ }^{14}$. Забегая немного вперед, следует сказать, что в передаче Эсхила, Этеокл достойно справился с задачей, поскольку завершающие строки трагедии гласят об Этеокле (Sept. 10801084, пер. С. Апта):

Ибо вместе с богами и Зевсом сами

Спас он город и не дал буйным волнам

Чужеземного войска разрушить, свалить

И в пучину метнуть,

В море гибели Кадмову крепость.

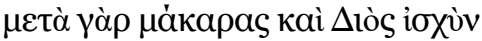

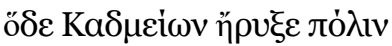

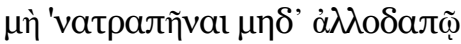

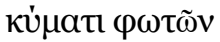

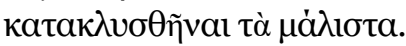

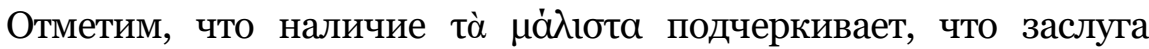
Этеокла больше, чем всех остальных, и это финальные слова Эсхила. Как же удалось Этеоклу больше всех других посодействовать делу спасения Фив? В первую очередь, по Эсхилу, ему удалось предотвратить панику, успокоив женское население (Sept. 110-286). Этеокл объясняет, что не нужно поддаваться панике, вопить, рассудок потеряв и стыд. Более того, он подчеркивает, что женщинам надо быть дома, а мужское

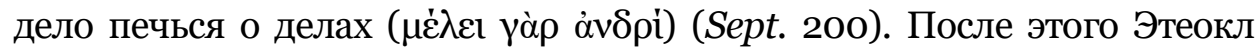
организует оборону в соответствии с крепостными воротами и находит нападавшим достойных противников среди защитников города, сам беря на себя задачу сразиться со своим братом Полиником у Седьмых ворот (Sept. 375-676). Причем, Этеокл подчеркивает, что именно он по справедливости должен сразиться с Полиником: «С начальником начальник, с братом брат и враг и с врагом сразится» (Sept. 674-675) (Пер. С. Апта) ${ }^{15}$.

\footnotetext{
14 бò $\delta$ ' Как видно из данного фрагмента, шторм на корабль города навлекает Арес.

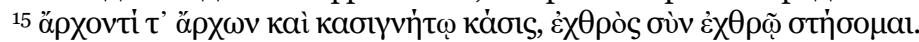


В заключение следует отметить, что в передаче Эсхила, Этеокл является практически исключительно положительным мужским персонажем и лишь в некоторых местах демонстрирует, что удержание им власти не было справедливым. Так, Эсхил вкладывает в уста

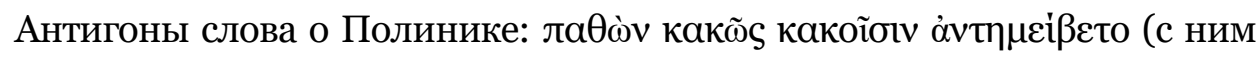
случилось зло и зло отдал взамен) (Sept. 1055). Однако перед лицом врага, Этеокл проявил лучшие мужские качества, которые позволили ему спасти город. Именно через речь Этеокла древнегреческий драматург передает идеалы мужества, в то время как сам Этеокл охарактеризован как храбрейший царь кадмейцев и разумный правитель.

\section{Литература}

Anderson A.S., The Seven Against Thebes at Eleusis, „Illinois Classical Studies” 2015, Vol. 40, No. 2, pp. 297-318.

Berman D.W., Cities-Before-Cities: 'Prefoundational' Myth and the Construction of Greek Civic Space, in Myth on the Map: The Storied Landscapes of Ancient Greece, ed. G. Hawes, Oxford 2017, pp. 32-51.

Bershadsky N., The Unbreakable Shield: Thematics of Sakos and Aspis, „Classical Philology" 2010, Vol. 105, No. 1, pp. 1-24.

Chadwick J., Linear B and related scripts, London 1987.

Hardie P.R., Imago Mundi: Cosmological and Ideological Aspects of the Shield of Achilles, „The Journal of Hellenic Studies” 1985, Vol. 105, pp. 11-31.

Liddel H.G., Scott R., A Greek-English Lexicon, 9th ed., 1940, with a Revised Supplement (edited by P.G.W. Glare, with the assistance of A.A. Thompson), New York 1996,

Lupack S., Mycenaean Religion, in The Oxford Handbook of the Bronze Age Aegean, ed. E.H. Cline, Oxford New York 2012, pp. 263-276.

Mills S., Theseus, Tragedy and the Athenian Empire, Oxford 1997.

Mozhajsky A. Yu., Pichugina V.K, The Greek shield as a metal artifact and its reflection in the story of the Croesus' gifts in Thebes, „Non-ferrous Metals” 2020, No.2, pp. 79-83.

Mozhajsky A. Yu., The myth of the War of the Seven and Pausanias' educational topography, „Hypothekai” 2020, No. 4, pp. 171-206.

Pichugina V.K., The shield as pedagogical tool in Aeschylus'Seven Against Thebes, „Hypothekai” 2020, No. 4, pp.121-170.

Symeonoglou S., The Topography of Thebes from the Bronze Age to Modern Times, Princeton 1985.

Yordanov S., The "Decline" of Bronze Age Wanax: The Phrygian vanak-, the PriestKing, the 'Wanax to Basileus Model' and the Power Relations in Phrygian Society, „The Journal Epohi [Epochs]” 2020, Vol. XXVIII, Iss. 2, pp. 249266. 
Zimmermann C., Der Antigone-Mythos in der antiken Literatur und Kunst, Tübingen 1993.

Можайский А.Ю., Реки и ворота Фив в трагедиях Эсхила, Софокла и Еврипида как часть образовательного пространства города, „Hypothekai” 2018, No. 2, C. 79-96.

\section{References}

Anderson A.S., The Seven Against Thebes at Eleusis, „Illinois Classical Studies”, 2015, Vol. 40, No. 2, pp. 297-318.

Berman D.W., Cities-Before-Cities: 'Prefoundational' Myth and the Construction of Greek Civic Space, in Myth on the Map: The Storied Landscapes of Ancient Greece, ed. G. Hawes, Oxford 2017, pp. 32-51.

Bershadsky N., The Unbreakable Shield: Thematics of Sakos and Aspis, „Classical Philology" 2010, Vol. 105, No. 1, pp. 1-24.

Chadwick J., Linear B and related scripts, London 1987.

Hardie P.R., Imago Mundi: Cosmological and Ideological Aspects of the Shield of Achilles, „The Journal of Hellenic Studies” 1985, Vol. 105, pp. 11-31.

Liddel H.G., Scott R., A Greek-English Lexicon, 9th ed., 1940, with a Revised Supplement (edited by P.G.W. Glare, with the assistance of A.A. Thompson), New York 1996.

Lupack S., Mycenaean Religion, in The Oxford Handbook of the Bronze Age Aegean, ed. E.H. Cline, Oxford New York 2012, pp. 263-276.

Mills S., Theseus, Tragedy and the Athenian Empire, Oxford 1997.

Možajskij A.Û., Reki i vorota Fiv v tragediâh Èshila, Sofokla i Evripida kak čast' obrazovatel'nogo prostranstva goroda, „Hypothekai” 2018, No. 2, S. 79-96.

Mozhajsky A. Yu., The myth of the War of the Seven and Pausanias' educational topography, „Hypothekai” 2020, No. 4, pp. 171-206.

Mozhajsky A. Yu., Pichugina V.K, The Greek shield as a metal artifact and its reflection in the story of the Croesus' gifts in Thebes, „Non-ferrous Metals” 2020, No.2, pp. 79-83.

Pichugina V.K., The shield as pedagogical tool in Aeschylus'Seven Against Thebes, „Hypothekai” 2020, No. 4, pp.121-170.

Symeonoglou S., The Topography of Thebes from the Bronze Age to Modern Times, Princeton 1985.

Yordanov S., The "Decline" of Bronze Age Wanax: The Phrygian vanak-, the PriestKing, the 'Wanax to Basileus Model' and the Power Relations in Phrygian Society, „The Journal Epohi [Epochs]” 2020, Vol. XXVIII, Iss. 2, pp. 249266.

Zimmermann C., Der Antigone-Mythos in der antiken Literatur und Kunst, Tübingen 1993 . 